\title{
Gim ASIK sebagai Metode Komunikasi Visual dalam Pengembangan Karakter Anak Usia Dini
}

\author{
Ferry Darmawan ${ }^{1}$, Puteri Saleha Nurhidayah ${ }^{2}$, Arif Hakim ${ }^{2 \bowtie}$ \\ Ilmu Komunikasi, Universitas Islam Bandung, Indonesia(1); Pendidikan Guru Pendidikan \\ Anak Usia Dini, Universitas Islam Bandung, Indonesia(2) \\ DOI: $\underline{10.31004 / \text { obsesi.v6i3.1932 }}$
}

\begin{abstract}
Abstrak
Fenomena yang terjadi saat ini anak-anak menghabiskan waktunya bermain dengan gawainya. Melihat kondisi ini, dapat menjadi hambatan pada pengembangan karakter anak. Solusi permasalahan diatas dikembangkanlah model komunikasi visual berbasis gim yang menarik bagi anak usia dini yaitu gim android ASIK (Agamis Sistematis Interaktif Kreatif). Subjek penelitian adalah anak usia 4-6 tahun sejumlah 30 orang. Adapun desain penelitian yang digunakan adalah desain kuantititatif "Quasi Experiment", adapun rancangan penelitian yang dipilih adalah "The Non Equivalent Control Group. Tujuan penelitian ini untuk mengetahui efektifitas gim ASIK terhadap pengembangan nilai moral dan agama anak usia dini dalam pengembangan karakter. Hasil penelitian menunjukkan terdapat perbedaan pada kelas eksperimen dan kelas kontrol setelah diberikan perlakuan gim ASIK di kelas eksperimen dan pembelajaran kovensional di kelas kontrol. Pada kelas eksperimen, anak-anak melakukan aktivitas mengikuti visualisasi yang ada dalam gim bertemakan pengembangan karakter dan mereka lebih cepat memahami dengan baik nilai karakter yang disampaikan.
\end{abstract}

Kata Kunci: pendidikan karater; game android; pengembangan moral dan agama.

\begin{abstract}
The phenomenon that occurs today is that children spend their time playing with their devices. Seeing this condition, it can become an obstacle to the development of children's character. The solution to the problem above is the development of a game-based visual communication model that is attractive to early childhood, namely the ASIK (Agamis Sistematis Interaktif Kreatif) android game. The research subjects were 30 children aged 4-6 years. The research design used is a "Quasi Experiment" quantitative design, while the research design chosen is "The Non Equivalent Control Group". The purpose of this study was to determine the effectiveness of ASIK games on the development of early childhood moral and religious values in character development. The results showed that there were differences in the experimental class and control class after being given ASIK game treatment in the experimental class and conventional learning in the control class. In the experimental class, the children carried out activities following the visualizations in the game with the theme of character development and they understood the value of the characters that were conveyed faster.
\end{abstract}

Keywords: character education; android-based game; creative interactive systematic religion, moral and religious development.

Copyright (c) 2022 Ferry Darmawan, et al.

$\triangle$ Corresponding author:

Email Address : arifhakim@unisba.ac.id (Bandung, Indonesia)

Received 9 August 2021, Accepted 10 January 2022, Published 14 January 2022 


\section{PENDAHULUAN}

Permasalahan berkembang dimana pada saat era Revolusi Indsutri 4.0 ini berkembang sangat pesat seolah melupakan nilai-nilai karakter (Pratama, 2019; Rozi, 2020; Wibowo, 2019). Membangun generasi penerus bangsa yang memiliki karakter merupakan tanggung jawab bersama. Pondasi awal dalam pendidikan adalah ditanamkannya pengetahuan moral sedini mungkin agar anak terhindar dari perilaku-perilaku yang akan menimbulkan pelanggaran (Fahrudin, 2014). Menurut Al Ghazali (Kamisah \& Herawati, 2019) bahwa pembinaan dan pendidikan mampu menghindarkan anak dari perilaku buruk dan mampu memberikan cara untuk mendapatkan kehidupan yang hakiki. Pengembangan pendidikan karakter di Lembaga PAUD erat kaitannya dengan lingkup pengembangan nilai agama dan moral. Sehingga arah pengembangan karakter tidak terlepas dari lingkup pengembangan pembiasaan di sekolah yaitu pengembangan nilai moral dan agama (Hakim, 2016).

Kehadiran revolusi industri 4.0 yang mengintegrasikan dunia industri dengan digital, mengharuskan masyarakat juga mampu menyesuaikan lingkungannya dengan berbagai macam inovasi baik di segi industri maupun juga inovasi di kehidupannya. Perkembangan yang paling pesat di era industri 4.0 terjadi pada bidang Teknologi Informasi dan Komunikasi (TIK). Setiap saat muncul teknologi baru yang menyertai perangkat komunikasi digital yang diluncurkan. Banyak gawai keluaran terbaru yang memiliki fitur beragam, kompleks, canggih, dan menyuguhkan kelebihannya masing-masing. Masyarakat yang hidup di era revolusi industri 4.0 akan menghadapi keadaan di mana mereka harus melek teknologi digital.

Teknologi komunikasi yang bermula hanya fokus kepada pesan singkat atau pesan suara kini berkembang semakin kompleks dan multifungsi. Konvergensi media tak terelakan, dimana multiplatform dan melampaui media konvensional menjadi kata kuncinya. (Prastya, 2017) Kini, alat-alat komunikasi dapat digunakan sebagai media pembelajaran di berbagai jenjang Pendidikan. Menurut Darmawan dalam (Astuti et al., 2018) pembelajaran dengan menggunakan telepon seluler dinamakan mobile learning. Mobile learning pun dipandang mampu meningkatkan kualitas pembelajaran dengan mengikis keterbatasan ruang dan waktu.

Anak usia dini lebih mudah menangkap gambar bercerita jika dibandingkan dengan tulisan. Oleh sebab itu, untuk mengenalkan bahasa tulisan pada anak usia dini biasanya menggunakan bahasa gambar. Anak belajar bahasa dengan melihat dan mendengar. Apa yang dilihat dan didengar harus seiringan. Maka dengan melihat gambar pada media ajar, anak-anak akan lebih mudah menangkap pesan yang terkandung di dalamnya dan anak akan mudah berimajinasi (Adli \& Darmawan, 2021; Darmawan, 2007). Anak usia dini saat ini relatif sudah melek teknologi, setidaknya pada gawai smartphone. Demikian juga pemanfaatan dari gawai tersebut oleh anak yang cenderung digunakan untuk bermain gim merupakan sebuah keniscayaan yang hampir setiap anak melakukannya, oleh karenanya perlu kontrol dan pemantauan dari orangtua di rumah (Hanafi, 2020; Mujiono \& Sarah, 2021). Pengembangan media pembelajaran yang mengadopsi teknologi untuk anak usia dini menjadi tujuan penelitian ini. Salah satu upaya menjembatani perkembangan TIK di era industri 4.0 dengan pengembangan pendidikan karakter di sekolah, maka perlu inovasi dalam media pembelajaran. Oleh sebab itu, peneliti membuat sebuah aplikasi gim berbasis android dan didesain untuk mengembangkan karakter anak melalui pengembangan nilai moral dan agama.

Alih-alih terlibat dan menjelajahi lingkungan mereka, anak-anak cenderung menghabiskan sebagian besar waktu mereka bermain dan berinteraksi dengan teknologi layar sentuh. Anak-anak menggunakan teknologi layar sentuh untuk berbagai fungsi seperti menonton video, bermain gim, atau mendengarkan lagu. Teknologi layar sentuh telah mengubah cara anak-anak bermain, berinteraksi, dan belajar karena aplikasi interaktif teknologi layar sentuh yang menawarkan beberapa hiburan dan atraksi. Teknologi interaktif menjadi isu karena perkembangan motorik bergantung pada pengalaman motorik anak. (Daud et al., 2020) 
Media pembelajaran saat ini sudah dapat diakses pada gawai-gawai berbasis android seperti smartphone. Penelitian ini bertujuan mengungkapkan kehadiran media pembelajaran berbasis gim dan gawai android mampu membuat perbedaan terhadap hasil belajar pengembangan karakter nilai agama dan moral pada anak usia dini dibanding kelas konvensional. Hingga kini, pembelajaran yang dilakukan di lembaga PAUD atau Taman Kanak-kanak, sebagian besar masih menggunakan metode bermain, bercerita, dan bernyanyi menggunakan peraga umum, seperti buku cerita, boneka, papan tulis, dan sejenisnya.

Namun, seiring dengan kemajuan teknologi dan kegemaran anak-anak menggunakan smartphone, ditambah masa pandemi Covid-19 yang menyebabkan kegiatan sekolah tidak bisa dilakukan tatap muka, hal ini menjadi tantangan tersendiri bagi guru sehingga perlu ada inovasi dalam proses belajar mengajar, khususnya PAUD (Santika, 2020).

\section{METODOLOGI}

Gim ASIK merupakan hasil karya orisinil yang dibuat oleh peneliti untuk mengembangkan nilai moral dan agama pada anak melalui aplikasi berbasis android dan telah terdaftar HaKI (https://e-hakcipta.dgip.go.id/index.php/c?code= Njk1NzE3YTJjYTRkNDA1ZDI4MTk2NDFkZWRIMWNIODcK). Gim ini terdiri dari beberapa halaman visual dimana terdapat 5 kategori pada menu utama, yaitu kategori mengenal agama, menjaga kebersihan, hari raya Islam, perilaku terpuji, dan mengenal ibadah (Gambar 1). Menu ditampilkan dengan tombol bergambar yang dapat disentuh dan akan mengarahkan kepada menu-menu materi pengembangan karakter di dalamnya, dengan kombinasi gambar, suara, dan animasi.

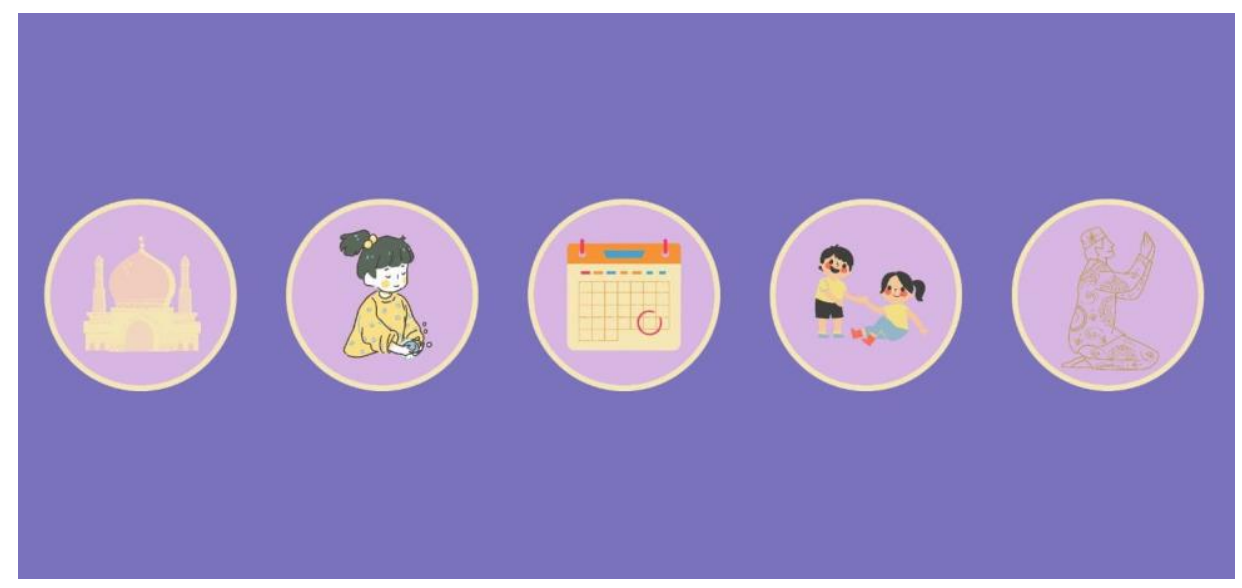

Gambar 1. Kategori dalam Aplikasi Gim ASIK ditampilkan dengan gambar atau simbol yang mewakili dan mudah diakses dengan sentuhan jari anak.

Dalam setiap kategori terdapat beberapa kuis sederhana yang disesuaikan dengan keterbacaan anak. Kuis tersebut disajikan dalam bentuk lagu, soal cerita, gambar, video, dan perintah sederhana. Sementara jawaban ditampilkan dengan gambar atau simbol yang mewakili sehingga anak-anak mudah memahami. Terdapat ragam pertanyaan atau kuis yang dapat dimainkan oleh anak dalam rentang waktu tertentu. Untuk mengatur durasi anak dalam menggunakan gawai sesuai waktu yang telah dibatasi, pada gim ASIK juga terdapat fitur timer yang dapat diatur pada saat membuka aplikasi ini diawal (Gambar 2). Melalui media yang dikembangkan oleh peneliti ini diharapkan nilai-nilai karakter dapat mudah terinternalisasi dari sisi kognitif, afektif, dan dilanjutkan dengan psikomotor yang mendukung pada nilai-nilai tersebut. Juga membiasakan anak untuk membatasi menggunakan gawai dalam durasi yang telah ditentukan. Tentunya perlu pendampingan juga dari orangtua atau guru. 


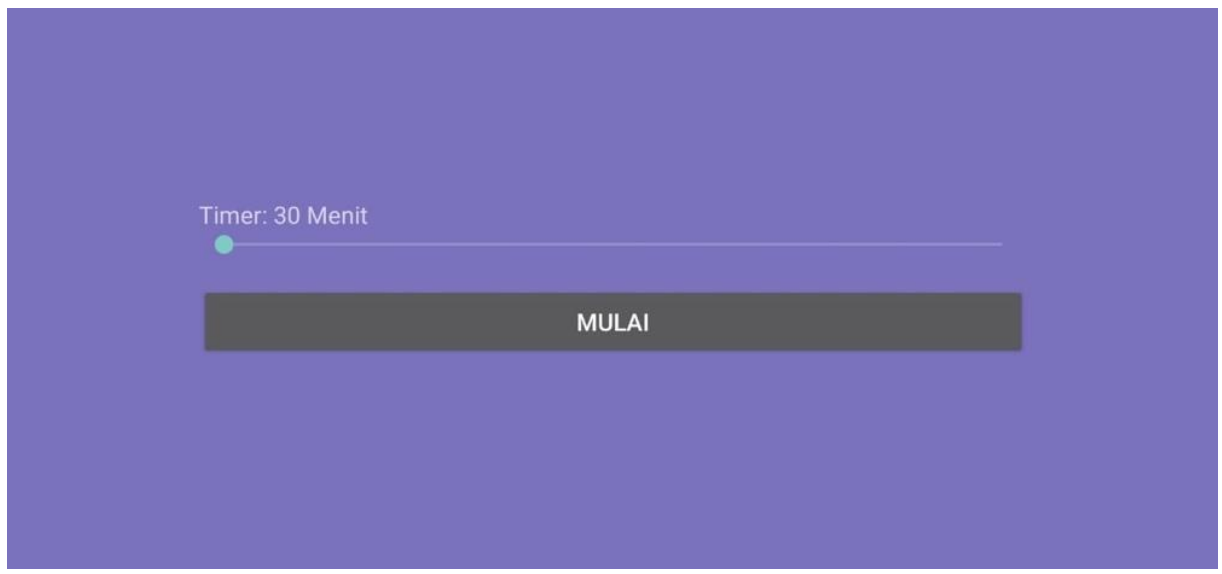

Gambar 2. Fitur pengaturan waktu untuk menggunakan gim ASIK.

Penelitian ini menggunakan desain penelitian kuantititatif "Quasi Experiment", adapun rancangan penelitian yang dipilih adalah "The Non Equivalent Control Group". Rancangan penelitian dipilih karena desain penelitian ini mengelompokkan dua kelas eksperimen secara teratur, untuk selanjutnya dapat dibagi menjadi kelas kontrol dan kelas eksperimen. Adapun, kelas eksperimen mendapatkan tindakan khusus sedangkan kelompok kontrol tidak. Tabel 1 menyajikan rancangan penelitian kuasi eksperimen (Yusuf, 2017).

Tabel 1. Rancangan penelitian Quasi Experiment “The Non-Equivalent Control Group"

\begin{tabular}{lccc}
\hline Grup & Pretest & Perlakuan & Postest \\
\hline Kelompok Eksperimen & $\mathrm{O}_{1}$ & $\mathrm{X}$ & $\mathrm{O}_{2}$ \\
Kelompok Kontrol & $\mathrm{O}_{3}$ & - & $\mathrm{O}_{4}$ \\
\hline
\end{tabular}

Penelitian ini digelar di RA Al-Ma'ruf dengan jumlah sampel sebesar 30 orang anak pada rentang usia 4-5 dan 5-6 tahun. Penelitian ini telah dilakukan uji etik telebih dahulu terkait pelaksanaan pemerolehan data kepada anak dan telah mendapatkan ijin dari komisi etik di jurusan. Teknik pengumpulan data hanya dilakukan melalui unjuk kerja. Unjuk kerja dilakukan agar dapat diketahui dinamika hasil belajar dari kedua kelas penelitian, sehingga nantinya dapat diukur apakah media pembelajaran gim ASIK ini memiliki hasil nilai signifkan dalam pengembangan nilai moral dan agama dibanding dengan kelas konvensional.

Adapun, cara pengambilan sampel pada penelitian ini dilakukan dengan menggunakan nonprobablity sampling dengan teknik Sampling Sistematis, yang artinya pemilihan sampel dilakukan dengan cara mengurutkan jumlah sampel yang telah ditentukan (Malik \& Chusni, 2018; Sugiyono, 2017). Sedangkan cara menentukan jumlah sampel yang telah diketahui jumlah populasinya, penulis menggunakan rumus hitung Yamane dan Isaac and Michael yang dikutip dari buku (Sugiyono, 2011). Rumus hitung penentuan jumlah sampel yang dibutuhkan adalah sebagai berikut:

$$
\begin{aligned}
\mathrm{n}= & \frac{N}{1+N(e)^{2}} \\
= & \frac{32}{1+32(0,05)^{2}} \\
= & 29.6(\text { sampel yang dibutuhkan dari jumlah } 32 \text { populasi dihitung dengan tingkat error } \\
& \text { sebanyak 5\%). }
\end{aligned}
$$


Dari jumlah di atas peneliti melakukan pembulatan sehingga jumlah sample yang dibutuhkan adalah 30 orang.

Selanjutnya instrument unjuk kerja disusun oleh peneliti dengan cara mengadopsi indikator pengembangan nilai moral dan agama pada Standar Tingkat Pencapaian Perkembangan Anak yang ada dalam Permendikbud 137 tahun 2014. Selanjutnya instrumen yang akan digunakan dilakukan uji validitas dan realibilitas, yatu dengan cara mengaplikasikan gim ASIK kepada sejumlah 30 orang anak dari sekolah yang berbeda dengan sekolah yang akan dijadikan subjek penelitian.

Adapun hasil uji validitas soal berdasarkan kepada harga $r$ hitung yang didapatkan dipadankan kepada $r$ tabel pada taraf signifikasi 5\%. Apabila $r$ hitung $>r$ tabel dapat dinyatakan butir soal yang diujikan bersifat valid. Pada hasil percobaan ini diperoleh harga $\mathrm{r}$ tabel $=0.602$. Hasil uji validitas disajikan pada Tabel 2.

Tabel 2 Uji Validitas Instrumen Penelitian

\begin{tabular}{ccc}
\hline Soal Valid & $2,3,4,11,12,13,15,18,19,20,21,22,24,25,26,30$, & 22 \\
$31,32,34,35,37,40$ & \\
\hline Soal Tidak Valid & $1,5,6,7,8,9,10,14,16,17,23,27,28,29,33,36,38$, & 18 \\
& 39 & 40 \\
\hline
\end{tabular}

Sedangkan hasil uji reliabilitas, Berdasarkan hasil penghitungan tersebut, dapat dinyatakan bahwa jumlah item yang diuji cobakan adalah sebanyak 40 buah dengan nilai Cronbachs's Alpha adalah $0.949>$ dari ketentuan 0.60, sehingga dapat dinyatakan bahwa butir soal pada instrument penelitian bersifat reliabel atau konsisten. Adapun hasilnya dapat dilihat pada Tabel 3.

Tabel 3. Uji Reliabilitas Instrumen Penelitian

\begin{tabular}{rr}
\hline $\begin{array}{c}\text { Cronbach's } \\
\text { Alpha }\end{array}$ & N of Items \\
\hline .949 & 40 \\
\hline
\end{tabular}

\section{HASIL DAN PEMBAHASAN}

Penelitian ini secara spesifik bertujuan untuk mengetahui perbedaan hasil belajar nilai moral dan agama berdasarkan tampilan visual, fitur audio, dan juga interaksi gerakan anak pada saat belajar dengan menggunakan aplikasi gim android ASIK (Agamis Sistematis Interaktif Kreatif). Penelitian ini dilaksanakan secara paralel di dua kelas yang telah ditetapkan dari 30 sample yang dipilih. Tahap pertama yang dilakukan adalah dengan melaksanakan pretest kepada 15 anggota sampel kelas kontrol dan juga 15 orang anggota kelas eksperimen. Tes tersebut dilaksanakan guna memperoleh kemampuan awal anak sebelum diberikan tindakan yang berbeda. Kedua kelas diperlakukan sama dalam pembelajaran pengembangan karakter, menggunakan metode umum seperti bercerita, ceramah, bernyanyi, atau bermain menggunakan peraga yang ada. Tabel 4 menjelaskan hasil belajar sebelum dilakukan percobaan pada kelas kontrol dan kelas eksperimen.

Berdasarkan hasil pada Tabel 4, dapat diketahui bahwa jumlah sampel yang melaksanakan uji pretest adalah sebanyak 30 orang. Kelas kontrol memiliki nilai rata-rata hasil belajar sebesar 40.53 dengan nilai terendah adalah 34 dan nilai tertinggi 52. Sedangkan pada kelas eksperimen diperoleh hasil sebesar 40.27 dengan nilai terendah ada pada nilai 32 dan nilai tertinggi di angka 55.

Tahap selanjutnya adalah memberikan tindakan yang berbeda kepada siswa, dimana kelas kontrol tetap dilanjutkan melakukan proses pembelajaran dengan metode konvensional 
sedangkan siswa pada kelas eksperimen melakukan pembelajaran dengan metode komunikasi visual menggunakan aplikasi gim ASIK. Pada kelas eksperimen, anak-anak dikenalkan dengan gim ASIK dan diberikan kesempatan berinteraksi langsung dengan gawai yang sudah terpasang aplikasi ASIK tersebut. Mereka tampak mengikuti rangkaian informasi dan gambar yang muncul diaplikasi dengan sesekali mengikuti kata-kata atau nyanyian yang di dengar, atau mengikuti gerakan yang diminta pada saat mengakses setiap kategori dalam gim tersebut.

Tabel 4. Hasil Pretest Pengembangan Nilai Moral dan Agama

\begin{tabular}{ccc}
\hline No. Responden & \multicolumn{2}{c}{ Hasil Belajar } \\
& Kelas Kontrol & Kelas Eksperimen \\
\hline 1. & 38 & 36 \\
2. & 36 & 35 \\
3. & 52 & 48 \\
4. & 46 & 32 \\
5. & 40 & 39 \\
6. & 39 & 42 \\
7. & 38 & 33 \\
8. & 49 & 39 \\
9. & 43 & 38 \\
10. & 38 & 42 \\
11. & 40 & 37 \\
12. & 45 & 42 \\
13. & 34 & 42 \\
14. & 36 & 55 \\
15. & 34 & 44 \\
\hline
\end{tabular}

Setelah tahap observasi selesai dilakukan untuk kedua kelas, selanjutnya dilakukan posttest untuk memperoleh perbandingan hasil belajar anak seperti dapat dilihat pada Tabel 5 .

Tabel 5. Hasil Belajar Posttest Nilai Agama Islam dan Moral

\begin{tabular}{ccc}
\hline No. Responden & \multicolumn{2}{c}{ Hasil Belajar } \\
& Kelas Kontrol & Kelas Eksperimen \\
\hline 1. & 45 & 56 \\
2. & 42 & 54 \\
3. & 53 & 72 \\
4. & 56 & 56 \\
5. & 54 & 57 \\
6. & 44 & 69 \\
7. & 46 & 48 \\
8. & 53 & 54 \\
9. & 57 & 52 \\
10. & 36 & 69 \\
11. & 47 & 57 \\
12. & 61 & 62 \\
13. & 42 & 60 \\
14. & 47 & 65 \\
15. & 42 & 63 \\
\hline
\end{tabular}


Diketahui bahwa jumlah sampel yang melaksanakan uji postest pada masing-masing kelas penelitian adalah sebanyak 15 orang. Kelas kontrol memiliki nilai rata-rata hasil belajar sebesar 48.33 dengan nilai terendah adalah 36 dan nilai tertinggi 61. Sedangkan pada kelas eksperimen diperoleh hasil sebesar 59.60 dengan nilai terendah ada pada angka 48 dan nilai tertinggi di angka 72 .

Berdasarkan hasil uji t-independent yang telah dilaksanakan, pretest hasil belajar pengembangan nilai moral dan agama pada pesrta didik di RA Al-Ma' ruf memiliki nilai Sig. 2 tailed adalah sebesar 0.898 lebih besar dari ketentuan 0.05 sehingga dapat dinyatakan hasil belajar tersebut tidak memiliki perbedaan yang signifikan. Sedangkan hasil belajar saat posttest memiliki hasil Sig. 2 tailed sebesar 0.000 lebih kecil dari ketentuan 0.05 . Sehingga dengan dasar penghitungan tersebut, hasil belajar pada pengembangan nilai moral dan agama di RA AlMa'ruf pada penggunaan aplikasi Gim ASIK dengan metode konvensional memiliki perbedaan yang signifikan dengan taraf kepercayaan sebesar $95 \%$.

Secara visual, tampilan Gim ASIK mampu membawa perbedaan terhadap hasil belajar pengembangan nilai moral dan agama di RA Al-Ma'ruf karena gambar-gambar yang ditampilkan memiliki ragam warna sehingga menarik perhatian anak. Tampilan tersebut mampu membuat anak melakukan pengamatan pada gambar yang disajikan Anak-anak yang cenderung memiliki tipe belajar visual dapat menyebutkan macam-macam peristiwa yang terdapat pada gambar yang muncul pada media pembelajaran. Anak-anak dengan tipe visual juga mampu untuk menyebutkan apa-apa saja yang terdapat pada gambar yang sedang ditampilkan (Gambar 4). Dengan demikian, anak mampu memahami makna dari gambargambar yang disajikan dalam aplikasi gim ASIK secara utuh, sehingga membantunya dalam mendapatkan informasi baru yang dapat membuat perbedaan terhadap hasil belajarnya. Berbagai penelitian yang sejenis tentang pengaruh media visual mampu meningkatkan hasil belajar siswa pada jenjang berbeda di tingkat SMP dan SMA, seluruhnya menunjukkan hasil yang signifikan didalam pembelajaran IPA, IPS, KIMIA, Ekonomi dan Matematika. (Agustina, 2015; Badruzaman, 2015; Soebroto et al., 2009; Suta Widura, 2018). Kreativitas guru dalam menciptakan dan menggunakan media visual secara efektif dan efisien menyebabkan peserta didik menjadi antusias mengikuti proses pem- belajaran (Jatmika, 2005).

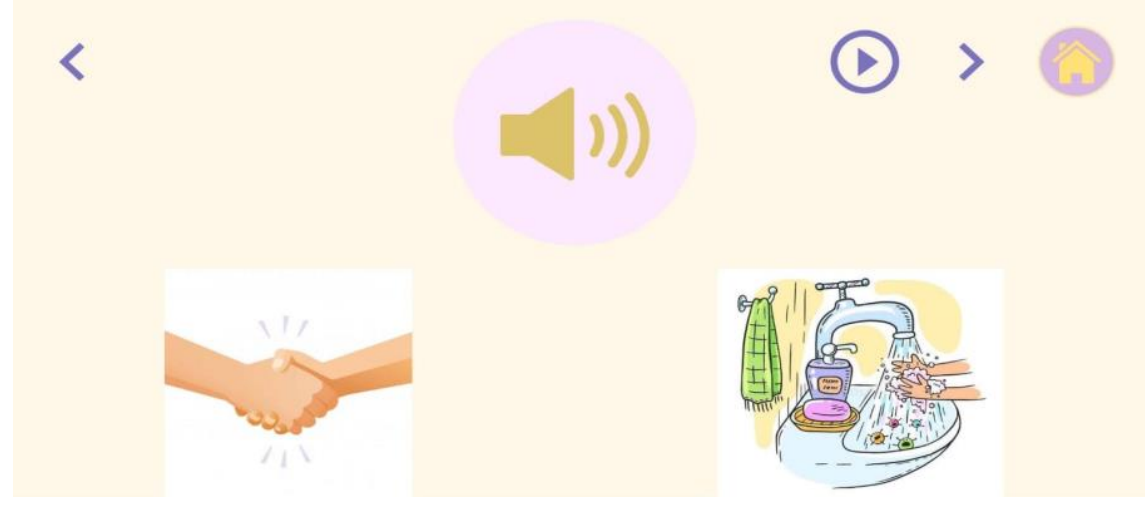

Gambar 4. Tampilan visual gim ASIK yang sederhana, berwarna cerah, dan mudah dipahami oleh anak.

Fitur audio dalam aplikasi gim ASIK memiliki intonasi dan pengucapan yang jelas sehingga dapat menarik indra pendengaran anak. Bagi anak yang memiliki tipe belajar secara audio, mereka menampilkan respon yang menarik, yaitu secara reflek ikut bergumam dan bahkan mulai bernyanyi mengikuti iringan lagu yang diputar. Dalam hal ini, irama dari lagu tersebut mampu mendorong anak untuk dapat mengikuti lirik yang dinyanyikan, sehingga anak mampu untuk memahami materi pengembangan nilai moral dan agama pada media pembelajaran yang dipergunakan. Artinya, dengan dapat mengikuti lagu-lagu dan intonasi dari kuis sederhana yang disajikan, anak dapat mengingat materi pengembangan nilai moral dan agama dengan cara yang unik. Hal ini lah yang mendorong anak untuk dapat memiliki 
hasil belajar yang berbeda dibandingkan dengan anak-anak yang belajar dengan metode konvensional.

Interaksi anak pada penggunaan aplikasi gim ASIK sebagai media pembelajaran pengembangan nilai moral dan agama menujukkan hasil yang beragam. Anak-anak dengan tipe belajar kinestetik mampu memahami perintah yang disajikan pada media pembelajaran secara penuh. Mereka yang mencerna informasi melalui gerakan, secara spontan langsung melakukan instruksi yang diberikan. Misalnya langsung berdiri dan melakukan gerakan sholat sesuai dengan apa yang ditampilkan pada aplikasi. (Gambar 5) Beda halnya pada anak yang gaya belajarnya bukan tipe kinestetik, ia lebih memilih untuk tetap duduk dan hanya memperhatikan gerakan sholat yang diputar. Pada saat alunan lagu diperdengarkan, anak dengan tipe belajar secara kinestetik merespon dengan melakukan gerakan badan, seperti bergoyang sesuai irama dan juga sesuai dengan lirik lagu yang ia dengar. Hal itulah yang mendorong anak dengan tipe belajar kinestetik mampu memahami materi belajar dengan lebih baik. Melalui gerakan, maka anak dengan tipe kinestetik lebih tertarik untuk belajar. Sehingga hasilnya anak mampu memiliki perbedaan hasil belajar apabila dibandingkan pada anak-anak yang tidak belajar dengan menggunakan aplikasi "Gim ASIK".
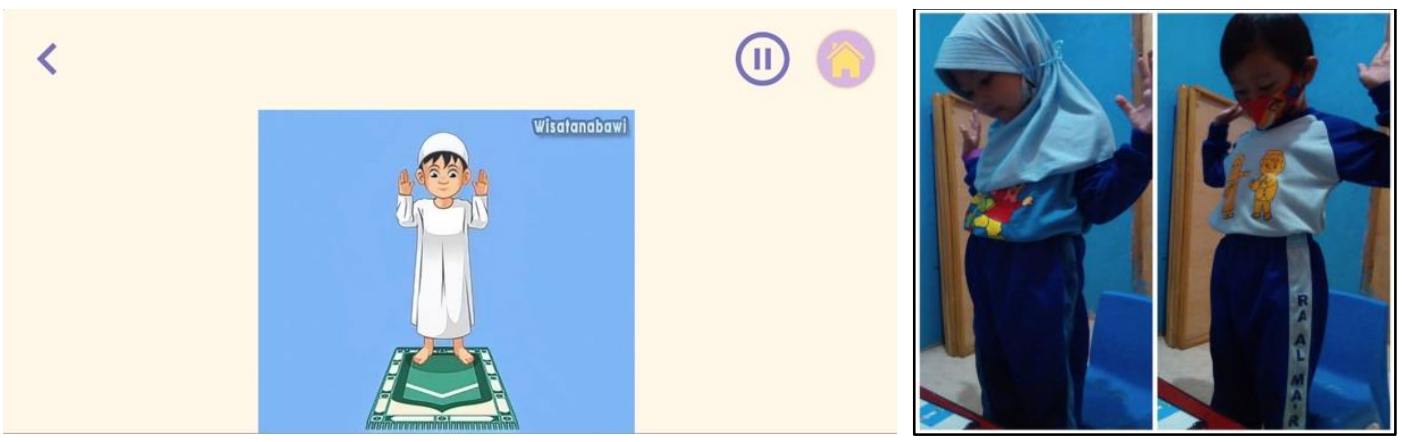

Gambar 5. Interaksi anak dengan gim ASIK dalam menirukan gerakan sholat

Berbagai upaya yang telah dilakukan didalam mengembangkan pendidikan karakter pada anak, diantaranya melalui pemainan tradisional (Hidayati, 2020; Jiwandono et al., 2020), media cerita interaktif melalui pendekatan AEINS (Adaptive Educational Interactive Narrative System), yang dapat mendukung perkembangan moral pada anak usia 8 tahun (Hodhod, 2010), hingga melalui media di era sekarang misalnya aplikasi gim interaktif (Pramono, 2021), aplikasi berbasis Android (Ardani et al., 2020) sampai pada platform Augmented Reality (Sarosa et al., 2019).

Media pembelajaran dengan format gim multimedia mampu menciptakan aktivitas belajar yang menyenangkan dan disukai oleh anak-anak, sehingga akan mudah menyerap ke dalam memori anak. Gim dengan format android khususnya memiliki kelebihan dimana, pada saat anak bermain gawai, mereka akan merasa sedang bermain gim tetapi secara tidak disadari oleh anak mereka sedang belajar tentang pendidikan karakter untuk anak.(Amalia et al., 2022). Generasi termuda saat ini, yang terutama disasar oleh pendidikan karakter, lahir menghadapi TIK yang sudah maju, sehingga mereka dapat menggunakan potensi TIK untuk meningkatkan proses pembelajaran. TIK akan berperan dalam mempengaruhi kurikulum dan lingkungan (baik fisik maupun virtual) dalam proses pembelajaran.

\section{SIMPULAN}

Pengembangan karakter anak usia dini di sekolah diimplementasikan melalui metode belajar sambil bermain. Upaya yang dikembangkan adalah memanfaatkan gim berbasis android, yang digemari anak di era digital sekarang. Metode komunikasi visual ini meningkatkan pengetahuan dan interaksi anak dalam pengembangan karakter moral dan nilai islami, karena tanpa disadari oleh anak yang sedang diterpa pengetahuan alih-alih 
bermain gim. Materi gim bisa disesuaikan dengan Permendikbud RI No. 137 tahun 2014 tentang standar nasional pendidikan anak usia dini karena dibuat sendiri oleh guru. Oleh sebab itu, perlu penguasaan teknologi komunikasi bagi guru untuk bisa mengikuti perkembangan zaman dalam dunia pendidikan anak usia dini agar tidak tertinggal oleh cepatnya globalisasi dalam pendidikan.

\section{UCAPAN TERIMA KASIH}

Terima kasih kepada DIPA Direktorat Jenderal Penguatan Riset dan Pengembangan Kementerian Riset, Teknologi, dan Pendidikan Tinggi DIPA Direktorat Jenderal Pendidikan Tinggi, Kementerian Pendidikan, Kebudayaan, Riset, dan Teknologi yang telah membiayai penelitian ini. Juga kepada LPPM Unisba yang telah memfasilitasi proses pengajuan proposal penelitian.

\section{DAFTAR PUSTAKA}

Adli, A. N., \& Darmawan, F. (2021). Ilustrasi Komik Sebagai Alat Penyampaian Berita. Prosiding Jurnalistik, 7(1), 125-131.

Agustina, L. (2015). Pengaruh Penggunaan Media Visual dan Minat Belajar Siswa terhadap Hasil Belajar Matematika. Formatif: Jurnal Ilmiah Pendidikan MIPA, 1(3), 236-246. https:// doi.org/10.30998/formatif.v1i3.74

Amalia, R., Akbar, Z., \& Nurani, Y. (2022). Pengembangan Media Game Edukasi Adventure Cooking untuk Meningkatkan Perilaku Prososial Anak Usia Dini. Jurnal Obsesi : Jurnal Pendidikan Anak Usia Dini, 6(3), 1501-1513. https:// doi.org/10.31004/obsesi.v6i3.1697

Ardani, N. L. P., Dermawan, K. T., Arthana, I. K. R., \& Putrama, I. M. (2020). The development of "i Sangging Lobangkara" balinese folklore as an android based game. Journal of Physics: Conference Series, 1516(1). https://doi.org/10.1088/17426596/1516/1/012012

Astuti, I. A. D., Dasmo, D., \& Sumarni, R. A. (2018). Pengembangan Media Pembelajaran Berbasis Android Dengan Menggunakan Aplikasi Appypie Di Smk Bina Mandiri Depok. Jurnal Pengabdian Kepada Masyarakat, 24(2), 695. https://doi.org/10.24114/jpkm.v24i2.10525

Badruzaman, A. dkk. (2015). Pengaruh Penggunaan Media Visual Terhadap Hasil Belajar Siswa Pada Materi Peta. PEDADIDAKTIKA: Jurnal Ilmiah Pendidikan Guru Sekolah Dasar, 2(1), 118-128. https://doi.org/10.30998/formatif.v1i3.74

Darmawan, F. (2007). Bahasa Rupa Wimba dalam Komik " Flap Book " Anak-anak: Studi Analisis Isi. Mediator, 8(1), 15-24. https:// doi.org/10.29313/mediator.v8i1.1229

Daud, A. Z. C., Aman, N. A., Chien, C.-W., \& Judd, J. (2020). The effects of touch-screen technology usage on hand skills among preschool children: a case-control study. F1000Research, 9, 1306. https:// doi.org/10.12688/f1000research.25753.1

Fahrudin. (2014). Proses Pendidikan Nilai Moral di Lingkungan Keluarga sebagai Upaya Mengatasi Kenakalan Remaja. Jurnal Pendidikan Agama Islam-Ta'lim, 12(1), 41-54.

Hakim, A. (2016). Pengembangan Nilai-Nilai Agama dan Moral di Taman Kanak-Kanak. Jurnal Ta'Dib, 05(01), 1-114. https://doi.org/10.21831/jpa.v1i2.3018

Hanafi, A. (2020). Kecenderungan Anak Bermain Gawai Hubungannya Dengan Motivasi Dan Prestasi Belajar. EduBase: Journal of Basic Education, 1(1), 30. https:// doi.org/10.47453/edubase.v1i1.42

Hidayati, N. N. (2020). Indonesian Traditional Games: a Way to Implant Character Education on Children and Preserve Indonesian Local Wisdom. Istawa : Jurnal Pendidikan Islam, 5(1), 81. https:// doi.org/10.24269/ijpi.v5i1.2475

Hodhod, R. (2010). Interactive Narrative for Adaptive Educational Games: Architecture and an Application to Character Education. Artificial Intelligence, February. http://etheses.whiterose.ac.uk/909/ 
Jatmika, H. M. (2005). Pemanfaatan Media Visual Dalam Menunjang Pembelajaran Pendidikan Jasmani di Sekolah Dasar. Jurnal Pendidikan Jasmani Indonesia, 3(1), 8999.

Jiwandono, I. S., Nisa, K., Rosyidah, A. N. K., Hakim, M., \& Nasaruddin, N. (2020). The Implementation of the Movement for Strengthening Character Education in Primary Schools Through Lombok Traditional Games at SDN 44 Mataram. 465(Access 2019), 246-249. https:// doi.org/10.2991/assehr.k.200827.062

Kamisah, \& Herawati. (2019). Mendidik Anak Ala Rasulullah (Propethic Parenting) Educate Children with Rasulullah Method (Propethic Parenting ). Journal of Education Science (JES), 5(1), 33-42.

Malik, A., \& Chusni, M. M. (2018). Pengantar Statistika Pendidikan Teori dan Aplikasi. In Deepublish (CV Budi Utama). Deepublish (CV Budi Utama).

Mujiono, M., \& Sarah, S. (2021). Android-Based Learning Media Development to Improve Student Learning Achievement. Berkala Ilmiah Pendidikan Fisika, 9(2), 115. https://doi.org/10.20527/bipf.v9i2.8660

Pramono, A. et al. (2021). Character Thematic Education Game "AK@R" of Society Themes for Children with Malang-Indonesian Visualize. International Journal of Instruction, 14(2), 179-196. https://doi.org/10.29333/iji.2021.14211a

Prastya, N. M. (2017). Media Convergence and Human Resoucres Management in Sport Media Newsroom: Case Study in TopSkor Daily Newspaper. Jurnal Komunikasi Ikatan Sarjana Komunikasi Indonesia, 2(2), 57-64. https://doi.org/10.25008/jkiski.v2i2.70

Pratama, D. A. N. (2019). Tantangan Karakter Di Era Revolusi Industri 4.0 Dalam Membentuk Kepribadian Muslim. Al-Tanzim : Jurnal Manajemen Pendidikan Islam, 3(1), 198-226. https://doi.org/10.33650/al-tanzim.v3i1.518

R. M. Branch. (2009). Instructional design: The ADDIE approach. Springer Science \& Business Media.

https:/ / books.google.co.id/books?id=mHSwJPE099EC\&dq=Instructional+design:+T he+ADDIE+approach+\&lr=\&hl=id\&source=gbs_navlinks_s https:// doi.org/10.1007/978-0-387-09506-6

Rozi, B. (2020). Problematika Pendidikan Islam di Era Revolusi Industri 4.0. Jurnal Pendidikan Islam, 9(1), 33-47. https:// doi.org/10.38073/jpi.v9i1.204

Santika, I. W. E. (2020). Pendidikan Karakter pada Pembelajaran Daring. Indonesian Values and Character Education Journal, 3(1), 8-19.

Sarosa, M., Chalim, A., Suhari, S., Sari, Z., \& Hakim, H. B. (2019). Developing augmented reality based application for character education using unity with Vuforia SDK. Journal of Physics: Conference Series, 1375(1). https://doi.org/10.1088/1742$\underline{6596 / 1375 / 1 / 012035}$

Soebroto, T., Priatmoko, S., \& Siyamita, N. (2009). Pengaruh Media Visual Di Ruang Kelas Terhadap Minat Dan Hasil Belajar Kimia Siswa. Jurnal Inovasi Pendidikan Kimia, 3(1), 400-405.

Sugiyono. (2011). Metode Penelitian Kuantitatif, Kualitatif dan R\&D. Alfabeta.

Sugiyono. (2017). Statistika Untuk Penelitian. Alfabeta.

Suta Widura, I. D. G. (2018). Pengaruh Model Core Berbantuan Media Visual Terhadap Hasil Belajar Ipa. Journal for Lesson and Learning Studies, 1(3), 258-267. https://doi.org/10.23887/jlls.v1i3.15390

Wibowo, A. (2019). Penggunaan Media Sosial sebagai Trend Media Dakwah Pendidikan Islam di Era Digital. Jurnal Islam Nusantara, 03(02), 339-356. http://www.jurnalnu.com/index.php/as/article/view/141

Yusuf, P. D. A. M. (2017). Metode Penelitian Kuantitaif, Kualitatif \& Penelitian Gabungan. Kencana. 